\title{
Brain Disease Leading to Mental Illness: A Concept Initiated by the Discovery of General Paralysis of the Insane
}

\author{
J.M.S. Pearce \\ Department of Neurology, Hull Royal Infirmary, Kingston upon Hull, England
}

\section{Key Words}

Brain disease $\cdot$ Mental illness $\cdot$ General paralysis of the insane

\begin{abstract}
In the early 19th century the prevailing alienist (psychiatrists') view was that organic lesions did not cause madness. The history of general paralysis of the insane (GPI) rests on four early publications which changed this concept: Haslam's Observations on insanity, Bayle's Recherches sur l'arachnitis chronique, Calmeil's De la paralysie considérée chez les aliénés, and Esmarch and Jessen's Syphilis und Geistesstörung. Haslam's account is unconvincing, but Bayle's report linking mental alienation with organic brain disease was a polemic that opposed established teachings. Calmeil and Delaye emphasised clinicopathological correlation and stressed the importance of white matter disease in causing dementia. GPI was to prove a crucial starting point in which the causes of mental illness were slowly transformed from psychogenic disturbances of mind and spirits to organically determined diseases.

Copyright $\odot 2012$ S. Karger AG, Basel
\end{abstract}

\section{Introduction}

Syphilis has a long, intriguing and controversial history [1], elegantly expounded by Claude Quétel [2]. The name syphilis came from a Latin epic poem, Syphilis, sive morbus gallicus, written by Girolamo Fracastoro (Latin: Hieronymus Fracastorius) (1483-1553), a physician, astronomer, and poet of Verona in his work De contagione et contagiosis morbis in 1530 [3]. Syphilitic disease remains clinically important in the UK, having increased from 301 cases in 1997 to 3,749 cases in 2007, with outbreaks, frequently amongst homosexual men [4]. The rate of reported cases of syphilis in the U.S. rose for the seventh consecutive year by up to $12 \%$ between 2006 and 2007 (report from U.S. Centers for Disease Control and Prevention).

Garrison and Morton [5] cite Thomas Willis's description of general paralysis of the insane (GPI) in De anima brutorum (first edition quarto, 1672, pp 392-432). Although there are records of early instances of what may have been GPI, the first identifiable cases were described in Paris early in the 19th century. 'Périencéphalite chronique diffuse', or 'dementia paralytica' (synonyms for GPI) accounted for about $10 \%$ of asylum admissions. It most commonly afflicted men aged 20 to 40 with spastic

\footnotetext{
J.M.S. Pearce

Emeritus Consultant Neurologist

304 Beverley Road

Anlaby, East Yorkshire, HU10 7BG (England)

E-Mailjms.pearce@me.com
} 
Table 1. GPI: timeline

\begin{tabular}{ll}
\hline 1798 & Haslam's Observations on insanity [15] \\
\hline 1822 & $\begin{array}{l}\text { Antoine Laurent Jesse Bayle's Recherches sur l'arachnitis } \\
\text { chronique [17]; GPI is for the first time described as a dis- } \\
\text { tinct disease }\end{array}$ \\
\hline 1826 & Calmeil's De la paralysie considérée chez les aliénés [18] \\
\hline 1857 & $\begin{array}{l}\text { Esmarch and Jessen's Syphilis und Geistesstörung [8]; they } \\
\text { suggested that syphilis caused GPI }\end{array}$ \\
\hline 1905 & $\begin{array}{l}\text { Schaudinn and Hoffmann discovered Spirochaeta (trepo- } \\
\text { nema) pallidum [37] }\end{array}$ \\
\hline 1906 & $\begin{array}{l}\text { August Paul von Wassermann's serologic test [38] } \\
\text { Noguchi and Moore showed the syphilitic spirochaetes } \\
\text { (Treponema pallidum) in the brains of general paralysis } \\
\text { cases [39] }\end{array}$ \\
\hline 1917 & $\begin{array}{l}\text { Julius Wagner-Jauregg's discovery that induced malaria } \\
\text { could halt the progression of general paresis [12] }\end{array}$ \\
\hline 1944 & $\begin{array}{l}\text { Penicillin is introduced by Bernhard Dattner at Bellvue } \\
\text { Hospital in New York [11] }\end{array}$ \\
\hline
\end{tabular}

weakness of pyramidal tract disease, impaired personality and memory, mania, erratic judgment, apathy, violence, 'congestive attacks' and epilepsy. Argyll-Robertson pupils and concurrent tabes dorsalis were to become useful signs $[6,7]$. General paralysis typically presented 12 to 20 years after the primary Treponema pallidum infection. It is a chronic progressive mainly fronto-temporal meningoencephalitis, which historically was inevitably fatal. The cerebrospinal fluid is characterized by lymphocytic pleocytosis and high protein levels. Serological tests now include the non-treponemal Venereal Disease Reference Laboratory (VDRL) test and the treponemal T. pallidum particle agglutination assay (TPPA), T. pallidum haemagglutination assay (TPHA), and enzyme immunosorbent assay (EIA) IgG/IgM.

Originally, the causes were believed to be heredity, head trauma, excessive cold, fright, alcoholism, venery, or exhaustion. While Esmarch and Jessen [8] had asserted as early as 1857 that syphilis caused general paresis, the role of syphilis in causing these disorders was hotly debated. Jean Alfred Fournier (1832-1914) [9] and Sir Jonathan Hutchinson (1828-1913) [10] favoured a syphilitic aetiology. But proof was lacking till Schaudinn and Hoffman's discovery of the Spirochaeta pallidum in 1905. Before penicillin, probably introduced by Dattner at Bellvue Hospital in New York [11], the only treatments were io- dides and mercurials, until in 1917 Julius Wagner-Jauregg [12] (1857-1940) discovered that induced malaria could sometimes halt progression of general paresis.

\section{Early Publications}

The history of GPI (timeline, table 1) [13] rests on four early publications [14] which laid the way for future developments: Haslam's Observations on insanity [15], Bayle's Recherches sur l'arachnitis chronique [17], Calmeil's De la paralysie considérée chez les aliénés [18], and Esmarch and Jessen's Syphilis und Geistesstörung [8]. They were to prove a crucial starting point in which the causes of particular types of delirium and madness were slowly transformed from purely psychogenic disturbances of mind and spirits to organically determined diseases.

\section{Haslam's Observations on Insanity}

John Haslam (1764-1844), an apothecary to the Bethlem Hospital, is claimed [19] to have given the first description of GPI, which first appeared in Observations on insanity: with practical remarks on the disease, and an account of the morbid appearances on dissection (1798) [15] on page 120 :

Paralytic affections are a much more frequent cause of insanity than has been commonly supposed. In those affected from this cause, we are, on enquiry, enabled to trace a sudden affection, or fit, to have preceded the disease. These patients usually bear marks of such affection, independent of their insanity: the speech is impeded, and the mouth drawn aside; an arm, or leg, is more or less deprived of its capacity of being moved by the will: and in by far the greatest number of these cases the memory is particularly affected. Very few of these cases have received any benefit in the hospital; and from the enquiries I have been able to make at the private houses, where they have been afterwards confined, it has appeared, that they have either died suddenly from apoplexy, or have had repeated fits, from the effects of which they have sunk into a stupid state, and have gradually dwindled away.

Zelmanowits [19] states that in this text: 'The expansive form of the disease is here described for the first time. The report of a case identifiable as that of general paralysis of the insane appears on page 64 in the 1st (1798) and on page 115 in the 2 nd (1809) edition. It includes postmortem findings.'

In fact the Case XV JA. was a man, aged 42 , with gross but non specific pathology suggesting hydrocephalus and possibly chronic subdural haematoma: 
There was a greater quantity of water between the different membranes of the brain than has ever occurred to me. The tunica arachnoidea was generally opake and much thickened: the pia mater was loaded with blood and the veins particularly enlarged. On the forepart of the right hemisphere ...was a blotch of a brown colour several shades darker than the rest of the cortical substance: the ventricles were much enlarged and contained by estimation at least six ounces of water [16].

Bucknill and Tuke (1879) [20] noted: 'It would appear that Haslam first described the disease, (he) did not name it. Calmeil ... gave it a name and got the honour of the discovery.' Denis Leigh [21] doubted that Haslam described GPI as a clinical entity. He commented that only Case 15 might be considered to be general paralysis. As a case of GPI this description is not wholly convincing.

\section{Antoine Laurent Jessé Bayle (1799-1858)}

Antoine Bayle (fig. 1), a student of René Théophile Hyacinthe Laënnec, entered l'hospice de Charenton in 1816. Jean Etienne Dominique Esquirol (1772-1840) [22] had noted in Dictionnaire des sciences médicales that most patients suffering from dementia were also afflicted with paralysis, and that paralysis was a complication of the mental disorder. At about the same time he gave a detailed description of the physical symptoms of this paralysis and noted that death could soon be expected following its diagnosis. Trousseau [23] noted that this diagnosis could be found frequently in the casebooks of that asylum before Bayle arrived.

Bayle first presented his research in his medical thesis in 1822 [17]. His description of the autopsy finding, 'chronic arachnitis', rejected Jean Etienne Dominique Esquirol's view that paralysis was a complication of insanity. Bayle argued that paralysis was only one facet of a complex but distinct disorder, which included both mental and physical symptoms, and which was secondary to a chronic inflammation of the arachnoid. He described three stages $[17,24]$. The first, a mild paralysis, particularly affecting speech, and a monomania with grandiose ideas. The second stage was a generalized mania and a worsening spastic paralysis, and the third was dementia and severe paralysis. In each of six cases, he detailed the clinical course and the pathology of arachnoid inflammation.

The first of these cases, Claude-Francois L., was admitted to Charenton in October 1818, shortly after Bayle began his work there. On admission this patient was 'in a demented state, with ideas that are predominantly ambitious, and with his partial paralysis ....' Finding an inflammation of the arachnoid lining of the

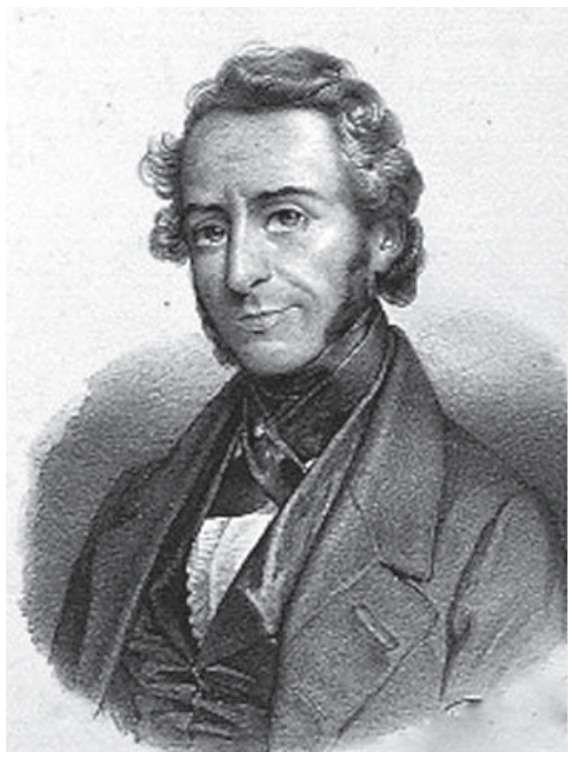

Fig. 1. Antoine Laurent Jessé Bayle (Credit: BIU Santé, Paris; http://www2.biusante.parisdescartes.fr/img/?refbiogr).

brain at autopsy, Bayle concluded that this explained all aspects of this patient's illness. After presenting the autopsy findings he asked rhetorically, 'Does not this observation prove that the disorder of the intellectual faculties was the symptom of a chronic arachnitis and not an essential delirium?' [25].

Bayle explained the difficulty with speech, staggering gait, agitation and monomania as results of the inflammation of the arachnoid lining and an outpouring of serous fluid which pressed on the brain. In the third period the trembling, loss of sphincter control and complete dementia were similarly explained as owing to chronic inflammation of the arachnoid and increasing pressure on the brain from serous exudate.

The prevailing alienist (psychiatrists') view was that organic lesions did not cause symptoms of madness. Bayle by contrast thought that 'madness is due to a physical lesion, most often a chronic inflammation of the meninges, but sometimes a specific or sympathetic irritation of the brain' [26]. Bayle's work would become one of the most important papers in the history of alienism (psychiatry). Later, in 1879, Jean Alfred Fournier (1832-1914) [9] would demonstrate the syphilitic origin of the process. Bayle's report linking mental alienation with organic brain disease was a polemic that opposed established teachings of Pinel and Esquirol [22]. The effect was dramatic, because it spawned many reports associating diverse mental disorders with brain lesions, a new and controversial concept [27]. In 1824 he founded 
Fig. 2. Louis-Florentin Calmeil. From $\mathrm{Mu}$ sée d'Histoire de la Médecine (Credit: BIU Santé, Paris; http://www2.biusante.parisdescartes.fr/img/?refbiogr).

Fig. 3. De la paralysie considérée chez les aliénés (http://www.jnorman.com/cgibin/hss/index.html).

2

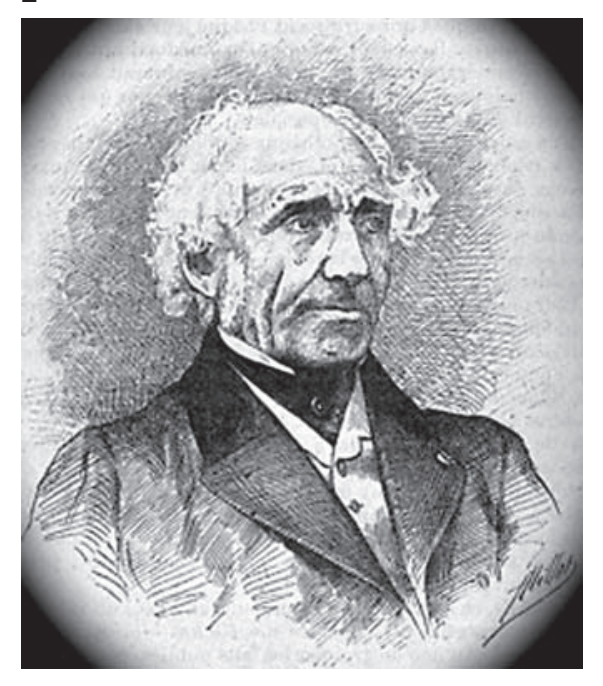

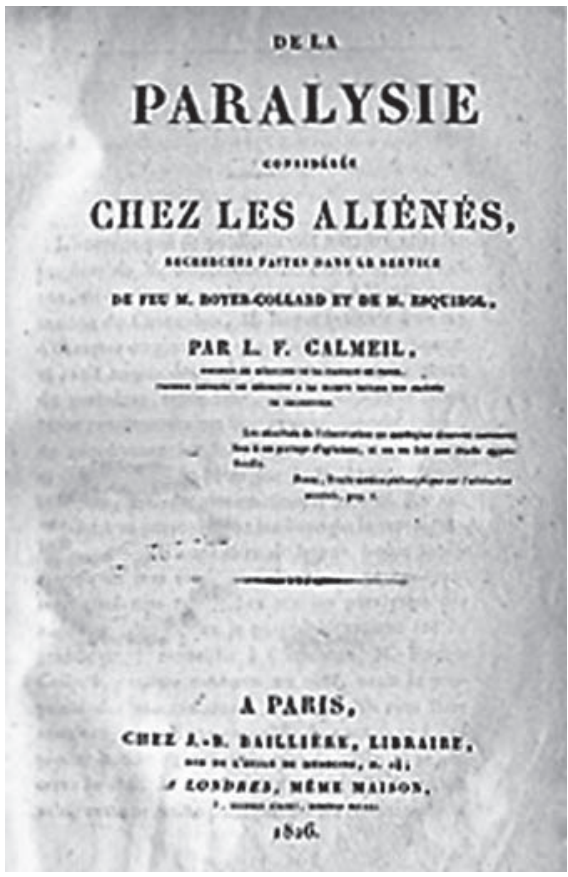

the journal Revue médicale, and from 1828 to 1837 was publisher of the multi-volume Bibliothèque de thérapeutique. But Bayle became an isolated figure who became ostracized because of the threat posed by his ideas; he left alienism [25].

\section{Louis Florentin Calmeil (1798-1895)}

In the same year that Bayle published his thesis [17], Louis-Florentin Calmeil (fig. 2), a psychiatrist (alienist) and pupil of Esquirol and M. Royer-Collard at the l'hospice de Charenton, also published a treatise [18], De la paralysie considérée chez les aliénés (fig. 3). His treatise contains a full description of GPI, in which he correlated the pathology with its clinical signs. Paralysis developed long after mental derangement in most patients; few survived more than three years in the paralytic stage. James Cowles Prichard's expansive and critical treatise of 1835 [28] stated that Esquirol was the first writer who directed attention to this morbid state and pointed out the incurable nature of insanity complicated with paralysis in the Dictionnaire des sciences médicales.

Calmeil, throughout his work, opposed Bayle's opinion that mental illness had a physical, organic basis since paralysis developed after mental derangement. Calmeil reported 60 cases of paresis with autopsy findings. His strategy was to correlate symptoms with pathology.
He described the early stages:

Changes in the character and habits, disorders of intelligence, delirium, much later alterations in the sensitivity and of motility. Rarely disorders of motor incoordination open the scene, unless encephalitis is preceded by a posterior myelitis.

In this first period, ... the individual keeps all the outward appearances of health. After a variable time is the second period.

Delirium increase, the reason disappears, emotional feelings are lacking, and the patient does not recognize even those around them. This gradual decline of the higher faculties is interspersed with paroxysmal phases of variable duration, so the delirium doubles and agitation becomes extreme; we see gnashing of teeth, muscle contractions, the twitchings of tendons. The muscles weaken, especially in the lower limbs, writing becomes illegible, the spelling has disappeared. The jaw trembles violently, stuttering is pronounced, memory is almost entirely destroyed. The senses, gait and pace weaken, vision is feeble, the sense of touch is dulled, and despite all the deteriorations, the somatic troubles are still rare, or negligible.

Finally comes the third period, the mind goes, the delirium has ceased, the voice is barely articulate, ... their head is no longer supported and falls on the chest, legs cannot support the weight of the body, the hands are unable to grasp ... swallowing no longer takes place only with extreme difficulty, and faeces and urine are discharged involuntarily. ... the mouth is dirty, foul breath, breathing rare, the pulse weak, small, intermittent, and death finally brings to end this inexorable decay. [18]

Calmeil could not confirm the pathogenesis proposed by Bayle. He reasoned that only an inflammation of the brain itself, not its covering membranes, could result in 
madness. Because he found a variety of lesions, he argued that these lesions could not 'sufficiently explain the symptoms observed during life' [18].

In defending himself against Calmeil's argument that only an inflammation of the brain, but not of the meninges could result in madness, Bayle countered by suggesting his view of the pathogenic significance of chronic meningitis was supported by its striking analogy with inflammations of other body linings, e.g. pleurisy. There remained a lasting polemic on the organic and moral causes of madness. In 1830 the debate on the organic causes of madness continued with the thesis of Esquirol's student, Etienne Georget (1795-1828), Dissertation sur les causes de la folie (1820), in which he criticized Pinel and Esquirol; Georget declared: 'I must not fear finding myself in opposition to my teachers ... by demonstrating that madness is a cerebral affliction'. It took more than 30 years for general paralysis to gain acceptance as a 'separate' disease.

Contemporary with Bayle and Calmeil, Jean Baptiste Delaye (1789-1879), a pupil of Esquirol (with A. Foville) won the Prix Esquirol on the causes of mental diseases. Esquirol championed Delaye as the first to describe the disease and for introducing the term 'incomplete general paralysis of the insane' [29]. Delaye recorded early signs, noting especially the slurred speech; he believed that the grey matter was the organ of intelligence, and the white matter and basal ganglia presided over locomotion. Delaye believed that white matter disorder caused the paralysis, whereas Bayle thought the primary change was a chronic arachnitis. Bayle's report was revolutionary in that it linked without doubt mental alienation with an organic brain abnormality [27].

\section{Syphilis the Culprit}

In the 1850 s, the cause of symptoms in 'périencéphalite chronique diffuse', as GPI was known, was uncertain. Bayle had commented: 'About one-fifth of the patients whom I observed, indulged in venereal excesses and often contracted syphilitic ailments. However, excesses of this kind and the illness which follows them are so frequent that I would not venture to include them among the predisposing causes of chronic meningitis.' Esmarch and Jessen [30] in 1857 were probably first to say that syphilis caused general paresis, but this was hotly debated. Jules Baillarger (1809-1890) in 1883 espoused a 'dualist' view: since the same mental symptoms could be seen in other conditions, Baillarger [31] believed that 'paralytic insan-

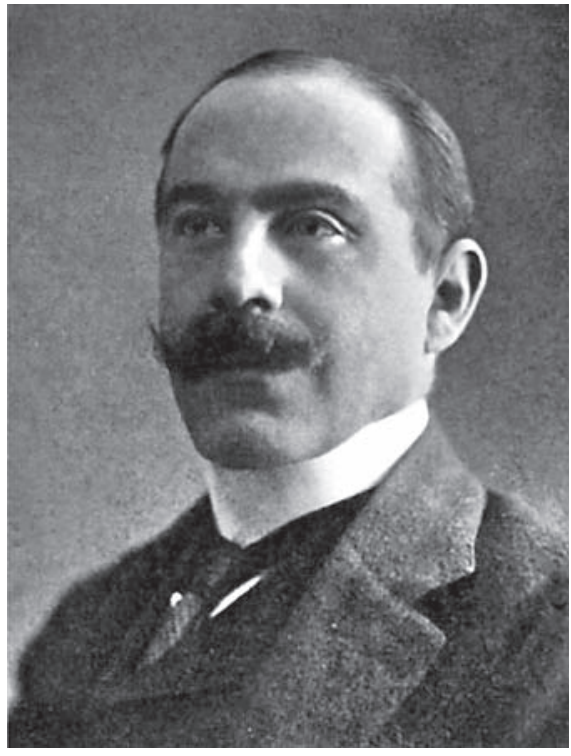

Fig. 4. August P. von Wasserman (http://en.wikipedia.org/wiki/ File:August_Wassermann.jpg).

ity and paralytic dementia are different conditions'. This separation of the lesion and symptoms, he thought, explained why some patients recovered.

Binswanger [32] in 1894 still believed that general paralysis was the consequence of a functional exhaustion of the brain, and distinguished it from his 'encephalitis subcorticalis chronica progressiva'. In Britain many uncertainties of nosology and aetiology remained. W.J. Mickle, superintendent of Grove Hall Asylum, London, published the first English book devoted to GPI in 1880, observing that nearly $13 \%$ of all male admissions to mental hospitals were suffering from GPI [33]. Dowse [34] doubted the relationship of spinal (presumably tabetic) to cerebral lesions in GPI, failing to discover any evidence as to why the two conditions should coexist. In 1883, Sir Thomas Clouston (1841-1915) first recognized juvenile paresis in relationship to congenital syphilis, on which Ibsen in 1881 based its portrayal in Oswald Alving in Ghosts (Gengangere). Clouston emphasized the entity of GPI but did not think there was proof of its syphilitic origin. In 1890, George H. Savage [35], at the Bethlem Royal Hospital, considered GPI 'a degeneration rather than a specific disease ... a disease of civilisation, and of the high pressure life of cities'. Despite the absence of effective treatment he advised about early warning signs of general paralysis in its earliest stage, detailing a myriad of symptoms and signs.

In 1901, Max Nonne published the first edition of his extensive textbook Syphilis und Nervensystem, which in- 
cluded GPI. The neuropathologist Sir Frederick Mott (1853-1926) [36] of the London County Asylums, Claybury, by analysing copious clinical and anatomical evidence, conclusively showed (before Wassermann's test) a link with syphilis. But, pace Fournier's notions of pseudoGPI, he regarded general paralysis as 'parasyphilitic', i.e. whilst syphilis was an essential factor in its causation there must be others, since only $3-5 \%$ of his primarily infected patients developed the disease. Like many contemporaries he was sceptical about the value of treatment.

The first two decades of the 20th century saw real progress, which rendered earlier conjectures obsolete. But proof was lacking until March 1905, when the zoologist Fritz Schaudinn (1871-1906), and Erich Hoffmann (18681959) in the Department of Dermatology at the Berlin Charite Hospital first observed the causative T. pallidum in a syphilitic pustule and in a lymph node [37]. The serological reagin test in 1906 of August Paul von Wassermann (1866-1925) (fig. 4) and Albert Neisser [38], and later treponemal haemagglutination, and fluorescent treponemal antibody-absorbed tests proved clinically invaluable. In 1913 all doubt about the syphilitic nature of GPI was finally dispelled when Noguchi and Moore [39] showed Spirochaetes (T. pallidum) in the brains of paretics.

\section{Treatments}

During the first half of the 19th century, the authorities on the treatment of syphilis were divided into mercurialists and non-mercurialists. Iodopin, introduced at the turn of the 20th century and Paul Ehrlich's arsphenamine (Salvarsan) were of little avail. Writing in Brain, Henry Head and E.G. Fearnsides noted:
The treatment of syphilis by modern measures is so expensive and troublesome that few inmates of our Asylums and Workhouse Infirmaries receive adequate injections of neosalvarsan or even effective mercurial treatment. No one wastes time and money on persons supposed to be obvious cases of 'general paralysis,'... [40]

Interestingly, Pinel in his Treatise on insanity in 1806 [41] had referred to quartan fever as a disorder operating to produce a 'permanency of recovery'. Eighty years later Julius Wagner-Jauregg (1857-1940), observing a striking remission of insanity in a woman with typhoid fever, and in two patients with erysipelas, reviewed 'The effect of feverish diseases on psychoses' [42]. He proceeded to inject nine cases of progressive paralysis (GPI) with tertian malaria. He obtained six remissions, three 'enduring' [12]. The treatment proved successful in Germany, Britain and America, with remissions in about $30 \%$ and partial remissions in $20 \%$ of patients [43]. He won the 1927 Nobel Prize 'for his discovery of the therapeutic value of malaria inoculation in the treatment of dementia paralytica' [44]. Wagner-Jauregg was a notorious eugenicist and anti-semite although his first wife Balbine Frumkin whom he divorced in 1903 was Jewish. He became a Nazi.

Almost 30 years passed before Penicillin [45] was shown to eradicate the treponemal Spirochaete and reverse the symptoms of early cases and halt progression of GPI [11].

\section{Disclosure Statement}

There are no conflicting interests or financial support.

\section{References}

1 von Hunnius TE, Roberts CA, Boylston A, Saunders SR: Histological identification of syphilis in pre-Columbian England. Am J Phys Anthropol 2006;129:559-566.

2 Quétel C: History of Syphilis. Baltimore, Johns Hopkins University Press, 1990.

3 Pearce JMS: The origins of syphilis. In: Fragments of Neurological History. London, Imperial College Press, 2003, pp 558-563.

-4 Cole MJ, Chisholm SA, Palmer HM, Wallace LA, Ison CA: Molecular epidemiology of syphilis in Scotland. Sex Transm Infect 2009; 85:447-451.
5 Norman JM (ed): Garrison \& Morton's Medical Bibliography, ed 5. Aldershot, Scolar Press, 1991, p 738.

6 Argyll Robertson DMCL: On an interesting series of eye symptoms in a case of spinal disease, with remarks on the action of belladonna on the iris. Edin Med J 1869;14:696.

7 Pearce JMS: The Argyll Robertson pupil. J Neurol Neurosurg Psychiatry 2004;75: 1345.

8 Esmarch F, Jessen W: Syphilis und Geistesstörung. Allg Zeitschr Psychiat 1857;14: 20-32.
9 Fournier JA: Syphilis du cerveau. Paris, Baillière, 1879.

10 Hutchinson J: Syphilis. Duodecimo volume. London, Cassell \& Co, 1887 and 1909.

11 Dattner B: Management of Neurosyphilis. New York, Grune and Stratton, 1944.

12 Wagner-Jauregg J: Über die Einwirkung der Malaria auf die progressive Paralyse. [On the effect of malaria on progressive paralysis]. Psychiat Neurol Wochenschrift 1918-1919; 20:132-134, 251-255.

13 Davis G: The cruel madness of love: sex syphilis and psychiatry in Scotland, 18801930. Amsterdam, N.Y., Editions Rodopi B.V., 2008 
14 Moore M, Solomon HC: Contributions of Haslam, Bayle and Esmarch and Jessen to the history of neurosyphilis. Arch Neurol Psychiat 1934;32:807-829.

15 Haslam J: Observations on insanity: with practical remarks on the disease, and an account of the morbid appearances on dissection, ed 1. London, Rivington, 1798.

16 Haslam J: Observations on madness and melancholy including practical remarks on those diseases together with cases and an account of the morbid appearances on dissection. London, Callow by G. Hayden, 1809, 115-117.

17 Bayle ALJ: Recherches sur l'arachnitis chronique. Paris, Thèse No. 247, 1822.

18 Calmeil LF: De la paralysie considérée chez les aliénés. Paris, J.B. Baillière, 1826.

19 Zelmanowits J: A historical note on the simple dementing form of schizophrenia. Proc $\mathrm{R}$ Soc Med 1953;46:931-932.

20 Bucknill JC, Tuke DH: A Manual of Psychological Medicine, ed 4. London, 1879, p 600.

21 Leigh D: John Haslam, M.D. 1764-1844, apothecary to Bethlem. J Hist Med 1955;10: $17-44$.

22 Esquirol JED: Des maladies mentales, tom 2. Paris, J.B. Baillière, 1838.

23 Trousseau A: Quelques mots sur l'historique d'une maladie cérébrale caracterisée le plus souvent par une paralysie générale et incomplète, compliquée de délire apyrétique. Arch Gen Med 1827;15:565.

24 Bayle ALJ: Traité des maladies du cerveau et de ses membranes. Maladies mentales. Paris, Gabon, 1826.
25 Brown EM: French psychiatry's initial reception of Bayle's discovery of general paresis of the insane. Bull Hist Med 1994;68:235-253.

26 Bayle ALJ: Nouvelle doctrine des maladies mentale. Rev Med 1825;169-215.

27 Bogousslavsky J, Moulin T: From alienism to the birth of modern psychiatry: a neurological story? Eur Neurol 2009;62:257-263.

28 Prichard JC: A treatise on insanity and other disorders affecting the mind. London, Sherwood, Gilbert \& Piper, 1835, p 947.

29 Delaye Jean-Baptiste: Considérations sur une espèce de paralysie qui affecte particulièrement les aliénés. Paris, Didot, Thèse No. 224, 1824.

30 Esmarch F, Jessen W: Syphilis und Geistesstörung. Allg Zeitschr Psychiat 1857;14: 20-32.

31 Baillarger J: Sur la théorie de la paralysie générale. Annales Médico-Psychologiques 1883;35:18-52, 191-218.

32 Binswanger O: Die Abgrenzung der progressiven Paralyse. Berliner Klinische Wochenschrift 1894;31:1137, 1182-1184.

33 Mickle WJ: General Paralysis of the Insane, ed 2. London, H.K. LEWIS, 1886. See also: Mickle WJ: The delimitation of general paralysis of the insane. 74th annual meeting BMA. Brit Med J 1906:741-748.

34 Dowse TS: On some points in the differential diagnosis of intracranial disease, general paralysis of the insane, and tabes dorsalis. BMJ $1882 ; 1: 731-732$.
5 Savage GH: The warnings of general paralysis of the insane. Br Med J 1890;1:777-780.

36 Mott FW: Syphilis and parasyphilis of the nervous system. Proc R Soc Med 1910; 3(Neurol Sect):35-49.

37 Schaudinn F, Hoffman E: Vorläufiger Bericht über das Vorkommen von Spirochaeten in syphilitischen Krankheitsprodukten und bei Papillomen. Arb Gesundh Amte (Berlin) 1905;22:527-534

38 von Wassermann AP, Neisser A, Bruck C: Eine serodiagnostische Reaktion bei Syphilis. Deutsche medicinische Wochenschrift, Berlin 1906;32:745-746.

39 Noguchi H, Moore JW: A demonstration of Treponema pallidum in the brain in cases of general paralysis. J Exp Med 1913;17:232238

40 Head H, Fearnsides EG: The clinical aspects of syphilis of the nervous system in the light of the Wassermann reaction and treatment with neosalvarsan. Brain 1914;37:1-140.

41 Pinel P: Treatise on Insanity, English ed., 1806, facs. edn. New York, Hafner, 1962, p 281.

42 Wagner-Jauregg J: Ueber die Einwirkung fieberhafter Erkrankungen auf Psychosen. Jb Psychiat Neurol 1887;7:94-131.

43 Whitrow M: Wagner-Jauregg and fever therapy. Med Hist 1990;34:294-310.

44 Shorter E: A history of psychiatry: from the era of the asylum to the age of Prozac. London, John Wiley, 1998, pp 193-195.

-45 Nicol WD, Whelen M: Penicillin in the treatment of neurosyphilis. J Vener Dis 1951;27: 132-141. 